\title{
Researching And Exploring a Mode of Training Innovative Talents in Electronic Information Professional of Higher Education by University-Enterprise Cooperation
}

\author{
Zhongxun Wang ${ }^{1, a,}$, , Kangkang Du ${ }^{1, b}$ \\ ${ }^{1}$ Institute of science and technology for Opto-Electronics information, Yantai University, Yantai, \\ Shandong, China \\ aytwzx3@126.com, bdkk@ytu.edu.cn \\ ${ }^{*}$ Corresponding author
}

\begin{abstract}
A training mode of university-enterprise cooperation is based on the industrial development and demand of enterprises. Enterprises participate in establishing and implementing the scheme for training talents in colleges and universities, which take advantage of solid theory in colleges and universities and enterprise's technology to enable the basic theory and operation skills of students to achieve the employment requirements of directly working in enterprises. Practice has proved that the implementation of a mode of training innovative talents in electronic information professional by university-enterprise cooperation can bring tripartite benefit among universities, enterprises and students.
\end{abstract}

Keywords: innovative talents, university-enterprise cooperation, higher education, electronic information.

\author{
王中训 ${ }^{1, a,{ }^{*}}$ 杜康康 ${ }^{1, b}$ \\ $1^{1}$ 烟台大学光电信息科学技术学院,烟台,山东,中国 \\ aytwzx3@126.com, bdkk@ytu.edu.cn \\ 通讯作者
}

高等教育电子信息类专业创新人才校企联合培养模式研究与探索

中文摘要. 校企联合培养模式是以产业发 展和企业需求为出发点, 企业参与高校人才 培养方案的制定与实施, 并利用高校扎实的 理论优势和企业的技术优势使学生在基础 理论和操作技能上达到进入企业能直接上 岗的要求。实践证明, 电子信息类专业创新 人才校企联合培养模式的实施, 可以带来高 校、企业、学生三方共赢的效果。
关键词：创新人才; 校企联合; 高等教育; 电 子信息

\section{1. 引言}

近年来随着国家信息产业的高速发展, 电子信息类专业的发展也日新月异, 行业市 场竞争日趋激烈, 对电子信息类专业人才的 
需求量呈逐年增加之势, 而目前高校对电子 信息类专业学生的培养模式仍然沿袭重理 论轻实践的传统教育模式, 所学知识及实践 环节不能与产业发展同步, 导致学生毕业后 不能适应企业对技术发展的需求, 同时也给 企业增加了无形的培养成本, 对学生、企业、 高校三方都不是共赢的方式。因此, 对电子 信息类专业人才培养模式的改革与探索就 变成了一个很重要的课题。校企联合培养模 式的研究就是在这样的背景下开始的。

校企联合培养模式是以产业发展和企 业需求为出发点, 由高校与企业签订人才联 合培养协议。企业参与高校人才培养方案的 制定与实施, 利用企业的专业资源对学生进 行培训, 不仅让学生能够学到扎实的理论知 识, 同时也让学生能够得到系统的实践技能 训练, 从而使学生在基础理论和操作技能层 次上达到进企业就能直接上岗的要求, 实现 电子信息类专业人才的培养与市场需求、产 业发展、企业生产同步互动、无缝链接。

\section{2. 校企联合培养模式理念}

“校企合作” 是 “校企合作教育” 的简 称, 国际上又称为 “合作教育”。世界合作 教育协会 (WACE) 对合作教育的解释是“利 用学校和企业两种不同的教育环境和教育 资源将课堂上的学习与工作中的学习结合 起来, 学生将理论知识应用于现实性的实践 中, 然后将工作中遇到的挑战和见识带回学 校促进学校的教与学” ${ }^{[1]}$ 。

目前, 校企联合培养模式在职业教育中 发挥着重要的作用。例如美国校企联合在90 年代形成气候, 初具规模, 其形式多种多样, 常见的有技术预科计划、职业实科中学、职 业主科计划、学徒培训计划等。而在国内, 部分职业教育采取企业把与学校对口的生 产车间直接搬进学校的模式、学校与企业建 立定期沟通机制的模式、与学校开设订单式 人才培养的模式、学校与企业组建职教集团 的模式等, 开展联合培养。而高等教育大部 分仍然偏重于理论知识的传授, 实践环节相 对滞后, 所学知识以及实践环节不能紧跟技 术发展的步伐, 导致学生走出校门不能及时 适应企业对技术发展的需求, 也有部分专业 在积极探索校企联合培养新模式, 也取得了
一定的成效, 但由于专业特点的限制, 不能 很好的进行推广。

\section{3. 校企联合培养模式的实施过程 ${ }^{[2]}$}

\section{1 充分调研企业、行业, 确立联合培养 合作单位}

企业的需求是联合培养模式实施的首 要条件。通过走访企业, 掌握企业的用人需 求, 是联合培养模式必经的环节。行业调研, 一是通过走访企业人事部门和技术部门, 了 解企业每年员工的招聘数量, 人才的类型, 企业对人才的知识和技能的要求等, 为学校 的专业设置、课程设置等提供决策依据; 二 是了解企业的先进技术, 特别是先进技术的 应用情况, 为学校理论教学提供现实参照; 三是通过调研了解企业的合作意向, 为学生 联系提供专业实习、实训的企业。目前学院 里的电子信息类专业积极拓展办学新思路, 经过认真的行业及市场调查, 通信工程专业 已与中兴通讯、物联网工程专业与浪潮正式 开展校企合作办学, 采用 $3+1$ 模式, 充分利 用校企合作办学资源, 培养高级应用型人 才。

\section{2 签订联合培养协议, 明确目标和职责}

校企双方一经签订联合培养协议, 则必 须严格遵守, 高校必须严格按联合培养协议 的要求来培养学生, 企业也需要全程参与联 合培养, 并吸纳经考察合格的学生进入企业 就业。在联合培养过程中, 高校的目标和职 责: 根据联合培养模式调整专业和课程设 置, 调整现有的教学计划, 以适应联合培养 的要求, 同时, 还要负责联合培养模式的学 生的日常管理、教育工作。而联合培养模式 下的企业的主要目标和职责: 落实学生的实 习和就业岗位, 同时负责学生的技能培训和 专业教育工作, 以利于学生能更好的适应企 业乃至行业的发展需求。

\section{3 制定校企联合培养方案, 实施培养工 作}

校企双方签订校企联合培养协议后, 就 进入了实施阶段。校企双方根据具体的行业 和企业需求制定方案, 高校就要组织学生实 施联合培养模式教学。在培养方案中要确定 
学生在校学习和到企业实习的具体时间安 排; 确定学校与企业各自负责实施的具体课 程和教学内容等。一般由高校负责通选课、 专业基础课和就业指导等课程的教学与考 核工作, 企业则负责先进的技术规范和技术 操作等一线工作需要的技能的教授工作。

\section{4 履行协议, 反馈培养效果}

符合联合培养协议要求的学生, 企业应 按校企联合培养协议招录其为企业正式员 工。同时, 高校尚需做好联合培养学生的就 业跟踪调查工作, 掌握企业对学生工作能力 的评价、学生入职后的岗位变化和薪酬状 况、学生对高校联合培养模式教育以及企业 招录后的培养工作的满意程度等, 从反馈信 息找出联合培养模式的薄弱环节并加以改 进, 以提高联合培养模式的实际功效。

\section{4. 校企联合培养的效果}

电子信息类专业人才校企联合培养模 式的实施, 将会带来高校、企业、学生三方 共赢的效果。首先, 对于企业而言, 经校企 联合培养的专业人才具备能迅速融入行业 的素质、知识和技能, 满足了企业发展、产 业进步对应用型人才的需求, 为企业大大缩 短了培训和实习周期, 降低了专业人才的二 次加工成本。其次, 对高校而言, 可以充分 将企业的技术优势与高校的理论基础深厚 的优势结合起来对学生全方位培养, 专业基 础课程教学突出学校的优势, 由学校教师承 担, 而专业前沿性课程, 则发挥企业技术优 势, 有企业选派高级工程师担任相关教学, 特别是实践性强的设计和实习等, 统一由企 业进行指导和安排。同时, 在校企联合培养 过程中, 可以逐步形成一套适应专业人才联 合培养需求的管理体系和管理制度, 同时研 究电子信息类专业联合培养效果考评和反 馈机制。对教学研究成果进行推广, 辐射相 关专业及其他院校, 促进各专业发展。最后, 对于学生, 校企联合培养模式使学生既有一 定的专业理论基础同时又能掌握一定的行 业前沿技术。有利于提升学生的创新意识和 实践能力, 增强了学生的核心竞争力, 拓宽 了就业渠道。

\section{结束语}

开展校企联合培养模式, 即一种以产业 发展和企业需求为出发点, 由学校和企业联 合培养的新型人才培养模式。可以使学生在 基础理论和操作技能层次上达到进企业就 能直接上岗的要求, 实现电子信息类专业人 才的培养与市场需求、产业发展、企业生产 同步互动、无缝链接。使高校、企业、学生 达到三方共赢的效果。

\section{References}

[1] Y. X. Zheng, The practice and study of the cultivation mode of talents in school enterprise, Journal of Mechanical Vocational Education, vol.3, pp. 8-9, 2009.

[2] Z. X. Wang and J. W. Zhao, The construction and Research on the practice teaching system for electronic information science and technology major, International Conference on Psychology, Management and Social Science, vol.01, 2013.

[3] R. C. Li , Y. Z. Shen and L. X. Jia, Exploring a new model of training innovative talents in electronic information by university-enterprise cooperation, Higher Education of Sciences, vol.01, pp. 150-152, 2012. 